\title{
PERSPECTIVE ON FOREST BIODIVERSITY INDICATORS FOR PROTECTED AREAS: A COMPARISON OF TURKISH AND SWEDISH FOREST EXPERT OPINIONS
}

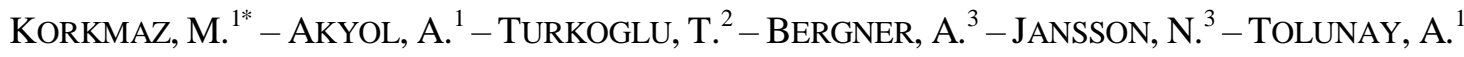 \\ ${ }^{I}$ Department of Forest Engineering, Faculty of Forestry, Suleyman Demirel University \\ 32260 Isparta, Turkey \\ ${ }^{2}$ Department of Forestry, Koycegiz Vocational School, Mugla Sitki Kocman University \\ 48800 Mugla, Turkey \\ ${ }^{3}$ IFM Biology, Conservation Ecology Group, Linköping University \\ SE-581 83 Linköping, Sweden \\ *Corresponding author \\ e-mail: korkmazmehmet32@gmail.com; phone: +90-246-211-3951, fax: +90-246-211-3948 \\ (Received 23 $3^{\text {rd }}$ Mar 2018; accepted $30^{\text {th }}$ May 2018)
}

\begin{abstract}
This paper presents a comparative analysis of expert opinions on forest biodiversity indicators for protected areas, using a questionnaire given to forest experts in Turkey and Sweden. Experts were selected according to whether they had studied or worked in areas related to biodiversity, protected areas and sustainable forest management. A Mann-Whitney $U$ test was used to determine the differences between the opinions of Swedish and Turkish experts regarding the indicators. The experts from both countries considered "endemic species" and "naturalness" as the most important indicators, while "overused species", "forest distribution and regeneration", "carrying capacity in terms of important species of area" and "the existence of different conservation status of protected areas" were considered equally as the least important indicators. The most important difference between the two groups was related to the indicators "dead wood" and "hollow trees", which Swedish experts found more important than their Turkish counterparts. Two other large differences were that the Swedish experts found "litter layer" much more important and Turkish experts instead found "plant species composition" much more important. The differences between the two groups reveal different perspectives regarding the planning and management of protected areas in each respective country.
\end{abstract}

Keywords: sustainable forest management, dead wood, hollow trees, Turkey, Sweden

\section{Introduction}

First introduced to the forestry literature in the 1990s, sustainable forest management criteria and indicators have been important tools for measuring the sustainability of forests (Mendoza and Prabhu, 2000; Brang et al., 2002). In 1992, the International Tropical Timber Association (ITTO) was the first to propose such criteria and indicators for tropical forests (ITTO, 1992, 2005). Subsequently, the annual Rio Summit highlights the importance of sustainable forest criteria and indicators, along with monitoring and reporting. (Castañeda et al., 2001; Rametsteiner, 2001; Mcdonald and Lane, 2004; Wolfslehner et al., 2005; Mrozek et al., 2006; Steenberg et al., 2013). Recently, the first step was taken towards the development of criteria and indicators for sustainable forest management for nine regional processes in the world. These processes include: the International Tropical Timber Organization (ITTO), Helsinki Process (MCPFE/Pan-European Process), Montreal Process, Tarapoto Proposal, Dry Zone Africa Process, African Timber Organization Process (ATO), Near East Process, 
Lepaterique Process of Central America and Dry Zone Asia Process (Akyol and Tolunay, 2014).

For these regional processes, seven key levels were identified as an overall framework for sustainable forest management. These levels include: the extent of forest resources, biodiversity, health and vitality of forest ecosystems, protective functions of forests, productive functions of forests, socio-economic functions, and legal, political and institutional framework (Castañeda, 2000; Siry et al., 2005; Purnomo et al., 2005; Grainger, 2012).

Among these levels, biodiversity criteria and indicators have been among the most debated since the Rio Summit. Until recently a great deal of effort has been undertaken to further develop the indicators for this criteria (Kotwal et al., 2008) because biodiversity refers to the dynamism, health, sustainability and energy of an ecosystem and its resilience against any kind of disturbance factor (Gülsoy and Özkan, 2008). In short, biodiversity is one of the fundamental bases for the continuity of life. Moreover, there are crucial challenges for ensuring the sustainability of biodiversity (Hagan and Whitman, 2006). These challenges arise because biodiversity is typically defined as the diversity of life measured at the levels of genes, species and ecosystems and the mutual interactions between these levels (Hagan and Whitman, 2006; Gaston, 1996; Claridge et al., 1997). Genetic structure is the primary component of vitality and is the basis of these levels.

The most important factor for the protection and sustainable use of biodiversity is the need to make a quantitative assessment of biodiversity (Duelli and Obrist, 2003). However, due to various challenges, the most practical approach for assessment is to use indicators related to biodiversity (Hagan and Whitman, 2006; Lindermayer et al., 2000). However, it is also difficult to identify and measure indicators for biodiversity (Heink and Kowarik, 2010) because the variables that can be practically surveyed and quantified are quite limited.

The main strategies developed to protect biodiversity and ensure its sustainability primarily include legal protection and the sustainable management of areas (Svancara et al., 2005). Protected areas that cover almost $12 \%$ of the Earth's surface are an important component of global protection strategies (Wells and McShane, 2004; Bajracharya et al., 2005). Although there are a broad spectra of indicators related to sustainable forest management, none of the abovementioned processes adequately describe protected areas (Blicharska et al., 2011; Tolunay and Akyol, 2015). This is because sustainable forest management processes utilize indicators that focus mainly on production forests across the world, which differ from protected areas.

Protected areas are of vital importance for biodiversity, and thus it is necessary to develop appropriate criteria and indicators. For example, one of the objectives of the "Integrated Approach to Management of Forests in Turkey, with Demonstration in High Conservation Value Forests in the Mediterranean Region" project implemented by the United Nations Development Programme is to develop biodiversity indicators in Turkey within the scope of sustainable forest management (UNDP, 2017).

The aim of this study was to evaluate biodiversity indicators that can be used for the sustainable management of protected areas, using opinions from experts. This data is then preliminarily presented for further discussion. From a global point of view, different or similar perspectives to various indicators are to be expected. Factors such as climate, geographical location, biodiversity, development level, and cultural features change the perceptions about and perspectives regarding protected areas in terms of 
nature conservation. To obtain some diverse perspectives, expert views were solicited about the protected areas in Turkey to represent Mediterranean forestry and from Sweden to represent Nordic forestry. We aimed to contribute to the protection and sustainable management of biodiversity in protected areas, which is of great importance at a global scale.

\section{Materials and methods}

The main materials of this study were comprised of indicators related to the protection, development and sustainability of biodiversity, which are among the criteria and indicators for sustainable forest management. The primary data was obtained from a survey conducted online in Turkey and Sweden. The secondary data was composed of information obtained from literature analyses and information, and documents and reports from various public entities and organizations (FAO, CIFOR, etc.).

The questionnaire was composed of multiple choice questions using a 4-point Likert scale (not important, less important, important and very important). The questionnaire contained a total of 27 questions divided into two parts. The first part asked about demographic features of the participating experts. The second part asked the experts to assess a set of biodiversity indicators developed from different sustainable forest management studies across the world (Table 1).

Table 1. The set of indicators ${ }^{1}$ prepared for the evaluation by the experts

\begin{tabular}{l|l}
\hline \multicolumn{1}{c|}{ Indicators } & \multicolumn{1}{c}{ Definition } \\
\hline Plant species composition & $\begin{array}{l}\text { The number and composition of plant species per forest types and } \\
\text { other wooded area types }\end{array}$ \\
\hline Naturalness & $\begin{array}{l}\text { The amount of forest types and other wooded area types divided in } \\
\text { natural, semi natural or plantation }\end{array}$ \\
\hline $\begin{array}{l}\text { Forest distribution } \\
\text { regeneration }\end{array}$ & The rates of natural regeneration and survival of tree species \\
\hline Sensitive and rare ecosystems & The amount and distribution of sensitive and rare ecosystems \\
\hline Dead wood & $\begin{array}{l}\text { The volume of standing and downed dead wood in different forest } \\
\text { types and other wooded area types }\end{array}$ \\
\hline Hollow trees & $\begin{array}{l}\text { The number of hollow trees and the proportion of the total amount of } \\
\text { trees or wood volume }\end{array}$ \\
\hline Litter layer & The litter and decaying condition \\
\hline Genetic resources & $\begin{array}{l}\text { The condition of forest genetic resources in the areas managed for seed } \\
\text { production, protected areas and other areas }\end{array}$ \\
\hline Ecosystem structure & The spatial structure of forest covers in the ecosystem level \\
\hline Endangered species & $\begin{array}{l}\text { The number of endangered forest species according to Red List } \\
\text { classification of International Union for Conservation of Nature } \\
\text { (IUCN) in relation to total number of forest species. (Threatened, rare, } \\
\text { vulnerable, endangered or extinct, mammals, birds other vertebrates or } \\
\text { invertebrates) }\end{array}$ \\
\hline Ondemic species & The population condition of endemic forest species \\
\hline The population condition for overused forest species \\
\hline of protected forests
\end{tabular}




\begin{tabular}{|c|c|}
\hline $\begin{array}{l}\text { Species whose distribution area } \\
\text { is declining and habitat loss }\end{array}$ & $\begin{array}{l}\text { The size of declining species distribution area and the existence and } \\
\text { status of forest habitat losses within protected areas }\end{array}$ \\
\hline $\begin{array}{l}\text { Major distribution areas and } \\
\text { population status of the species }\end{array}$ & The size of distribution area and population status for forest species \\
\hline $\begin{array}{l}\text { Carrying capacity in terms of } \\
\text { mportant species of area }\end{array}$ & apacity for imp \\
\hline Water resources and wetland & $\begin{array}{l}\text { The quality of water resources and wetlands in forests (Number and } \\
\text { area) }\end{array}$ \\
\hline Damaged areas & $\begin{array}{l}\text { The size and proportion of forest areas damaged by va } \\
\text { and factors (Pests, disease, fire and flood) }\end{array}$ \\
\hline Human use of protected areas & $\begin{array}{l}\text { The size and proportion of human uses } \\
\text { (Residential areas, agricultural areas, suc }\end{array}$ \\
\hline Effects of other sectors & $\begin{array}{l}\text { ther sectors (Mining, agriculture, livestock, } \\
\text { c.) }\end{array}$ \\
\hline $\begin{array}{l}\text { Existence of contaminants } \\
\text { around protected areas }\end{array}$ & The number, size and type of pollutants around protected forest areas \\
\hline $\begin{array}{l}\text { Differentiated conservation } \\
\text { status within protected areas }\end{array}$ & $\begin{array}{l}\text { The existence of areas with different conservation status within the } \\
\text { protected forest area (Status, size, cause etc.) }\end{array}$ \\
\hline $\begin{array}{l}\text { Other issues important } \\
\text { sustainable management }\end{array}$ & $\begin{array}{l}\text {-The availability and capacity of an institutional structure for the } \\
\text { management and existence of functional legislation } \\
\text { - The existence of economic policy framework and financial } \\
\text { instruments } \\
\text {-The educational and informational opportunities for implementation } \\
\text { of the policy framework } \\
\text {-the strengthening of knowledge about endangered species (inventory } \\
\text { or research) } \\
\text {-The management plans }\end{array}$ \\
\hline
\end{tabular}

${ }^{1}$ This set is based on the biodiversity indicators used in International Tropical Timber Organization (ITTO), Helsinki Process (MCPFE/Pan-European Process), Montreal Process, Tarapoto Proposal, Dry Zone Africa Process, African Timber Organization Process (ATO), Near East Process, Lepaterique Process of Central America, Dry Zone Asia Process, Center for International Forestry Research (CIFOR) processes at global level (FAO, 1996, 1997, 2003, 2004, 2010; CIFOR, 1999; ITTO, 2003, 2005; CCFM, 2004; MCPFE, 2006; MPCI, 2017)

In this study, the expert group consisted of specialists from universities and research institutions, experts at ministries of agriculture, forestry and environment related to protected areas, and NGO representatives in both Turkey and Sweden. Experts were selected according to whether they had studied or worked in areas related to biodiversity, protected areas and sustainable forest management. The interest areas and biographies of the experts were reviewed on their web sites.

Three-hundred participants who were assumed to be related to the subject were asked to participate in the study. The survey was submitted to Turkish and Swedish experts simultaneously between September and December 2016. The web link for the questionnaire was sent to Turkish and Swedish experts via email. During the survey, three reminders were given once a month. Ultimately, 122 experts from Turkey and 112 experts from Sweden participated in the survey. Therefore, the response rate was quite high (81.3\% for Turkish, $74.6 \%$ for Swedish experts), and we assumed that this rate was rather satisfactory (Nulty, 2008). The profile characteristics of the experts participating in the study are demonstrated in Table 2. One third of the experts in the study were women and the proportion of women was higher in the Swedish group. The Swedish 
group had a slightly lower average age than the Turkish group. Nearly $70 \%$ of the experts belonged to universities and research institutes. There was a higher proportion of experts from universities and research institutes in the Turkish group. The Swedish group had a higher proportion of experts from governmental institutions, but a lower proportion from NGOs.

Statistical analyses were conducted using Statistical Package Program (SPSS 20.0) and the results were evaluated at a significance level of 5\%. Cronbach's alpha coefficient was calculated as 0.856 , and was greater than 0.8 ; thus, the scale had high statistical reliability. The data obtained from the questionnaire had a non-parametrical distribution (Kolmogorov-Smirnov test, $\mathrm{p}<0.05$ ); therefore, a Mann-Whitney U test (Nachar, 2008) was used to determine the differences between the opinions of Swedish and Turkish experts regarding the indicators. According to the average of the responses given by the experts, the indicators were ranked starting from indicators that were considered the most important

Table 2. Profile characteristics of experts

\begin{tabular}{l|c|c|c|c|c|c}
\hline \multirow{2}{*}{ Characteristics } & \multicolumn{2}{|c|}{ Turkey } & \multicolumn{2}{c|}{ Sweden } & \multicolumn{2}{c}{ Total } \\
\cline { 2 - 7 } & $\boldsymbol{f}$ & $\boldsymbol{\%}$ & $\boldsymbol{f}$ & $\boldsymbol{\%}$ & $\boldsymbol{f}$ & $\boldsymbol{\%}$ \\
\hline Gender & & & & & & \\
Female & 34 & 27.9 & 46 & 41.1 & 80 & 34.2 \\
Male & 88 & 72.1 & 66 & 58.9 & 154 & 65.8 \\
\hline Age & & & & & & \\
$20-30$ & 10 & 8.2 & 24 & 21.4 & 34 & 14.5 \\
$31-40$ & 43 & 35.2 & 23 & 20.5 & 66 & 28.2 \\
$41-50$ & 41 & 33.6 & 40 & 35.7 & 81 & 34.6 \\
$51-60$ & 24 & 19.7 & 21 & 18.8 & 45 & 19.3 \\
60< & 4 & 3.3 & 4 & 3.6 & 8 & 3.4 \\
\hline Affiliation/Working Institution & & & & & & \\
University & 62 & 50.8 & 63 & 56.3 & 125 & 53.4 \\
Research Institute & 29 & 23.8 & 6 & 5.4 & 35 & 15.0 \\
Agriculture, forest and environment ministries & 16 & 13.1 & 25 & 22.3 & 41 & 17.5 \\
Non-governmental organization (NGO) & 9 & 7.4 & 3 & 2.7 & 12 & 5.1 \\
Other & 6 & 4.9 & 15 & 13.4 & 21 & 9.0 \\
\hline
\end{tabular}

\section{Results}

\section{Opinions of experts for biodiversity indicators related to forest species}

The opinions about the importance of endangered and endemic species as indicators between the Turkish and Swedish experts did not significantly differ (Table 3). In other words, the experts in both groups found these indicators equally important (Fig. 1).

The evaluated level of importance for the other five species indicators (Table 3) was statistically different $(\mathrm{p}<0.05)$ between the two groups. For all of these indicators, the level of importance given by Turkish experts was higher than that of Swedish experts (according to 4-point Likert scale) (Fig. 1). The least important species indicator in the evaluation was "overused species". It was also the indicator where the evaluation differed most between the groups. In total, $47 \%$ of Swedish experts found this indicator 
not and less important, while only $9 \%$ of the Turkish experts found this indicator less important.

Table 3. Mann-Whitney U test results for the importance of forest species indicators

\begin{tabular}{c|c|c|c|c}
\hline Indicators & M-Whitney U & Wilcoxon W & Z & p \\
\hline Endangered species & 6325.000 & 12653.000 & -1.798 & 0.072 \\
Endemic species & 6623.000 & 12951.000 & -0.853 & 0.393 \\
Overused species & 4085.000 & 10413.000 & -5.721 & $\mathbf{0 . 0 0 0}$ \\
Species whose lives depend on protected areas & 5889.500 & 12217.500 & -2.494 & $\mathbf{0 . 0 1 3}$ \\
Species whose distribution area is declining and habitat loss & 5924.000 & 12252.000 & -2.328 & $\mathbf{0 . 0 2 0}$ \\
Major distribution areas and population status of the species & 5985.000 & 12313.000 & -2.059 & $\mathbf{0 . 0 3 9}$ \\
Carrying capacity in terms of important species of area & 5123.500 & 11451.500 & -3.720 & $\mathbf{0 . 0 0 0}$ \\
\hline
\end{tabular}

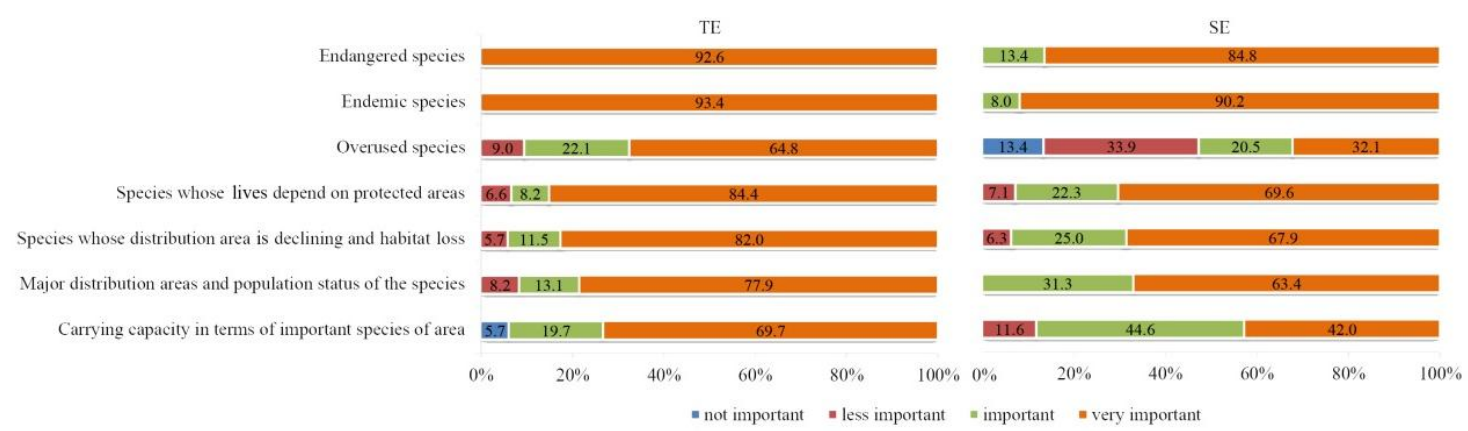

Figure 1. Differences in given level of importance for the forest species indicators. (Turkish experts: TE, Swedish experts: $S E, n_{T E}=122, n_{S E}=112$, only values $>5 \%$ )

\section{Opinions of experts for indicators related to conservation of natural heritage, genetic resources and some forest structures}

Genetic diversity refers to the diversity of genetic material and is assessed as the genetic difference in a specific species, population, variety, subspecies or race. The Turkish and Swedish experts found the indicators for genetic resources very important (Fig. 2), and there were no statistically significant differences found between the two groups (Table 4).

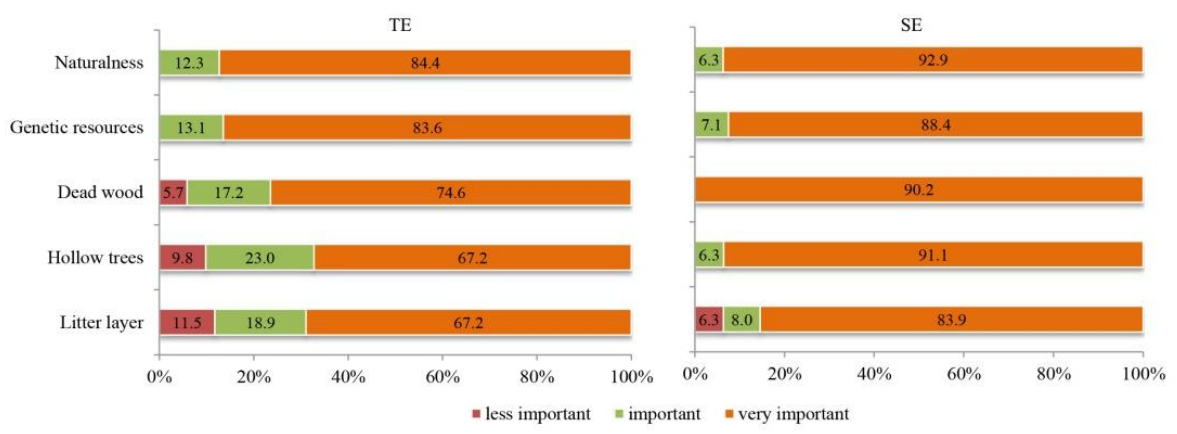

Figure 2. Differences in given level of importance for the conservation of natural heritage, genetic resources and some forest structures indicators $\left(n_{T E}=122, n_{S E}=112\right.$, only

values $>5 \%$ ) 
Turkish experts found the indicators for dead wood and hollow trees less important than their Swedish counterparts (Fig. 2). The opinion about the importance of the dead wood and hollow trees indicator differed significantly between Turkish and Swedish experts (Table 4). Similarly, the "naturalness" indicator was found more important by the Swedish experts (Fig. 2). Another significant difference was that the Swedish experts found litter layer more important than did Turkish experts.

Table 4. Mann-Whitney $U$ test results for the importance of conservation of natural heritage, genetic resources and some important structures in forests indicators

\begin{tabular}{c|c|c|c|c}
\hline Indicators & M-Whitney U & Wilcoxon W & Z & p \\
\hline Naturalness & 6249.500 & 13752.500 & -2.033 & $\mathbf{0 . 0 4 2}$ \\
Genetic resources & 6528.500 & 14031.500 & -0.971 & 0.332 \\
Dead wood & 5801.000 & 13304.000 & -2.984 & $\mathbf{0 . 0 0 3}$ \\
Hollow trees & 5202.000 & 12705.000 & -4.411 & $\mathbf{0 . 0 0 0}$ \\
Litter layer & 5720.500 & 13223.500 & -2.843 & $\mathbf{0 . 0 0 4}$ \\
\hline
\end{tabular}

\section{Opinions of experts for biodiversity indicators related to ecosystem}

Regarding biodiversity indicators related to ecosystem, there were different opinions between the two expert groups for "plant species composition" and "forest distribution and regeneration" (Fig. 3). These indicators were found relatively more important by the Turkish experts and were statistically different (Table 5).

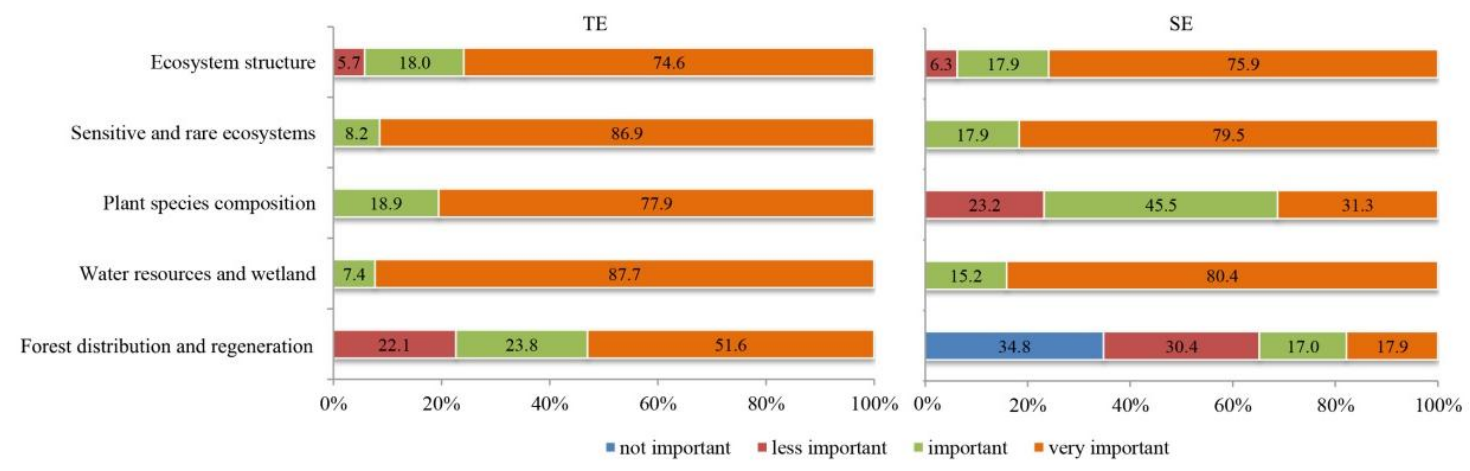

Figure 3. Differences in given level of importance for ecosystem indicators $\left(n_{T E}=122\right.$,

$$
n_{S E}=112 \text {, only values }>5 \% \text { ) }
$$

Table 5. Mann-Whitney U test results for the importance of ecosystems indicators

\begin{tabular}{c|c|c|c|c}
\hline Indicators & M-Whitney U & Wilcoxon W & Z & P \\
\hline Ecosystem structure & 6723.000 & 14226.000 & -0.279 & 0.780 \\
Sensitive and rare ecosystems & 6374.500 & 12702.500 & -1.366 & 0.172 \\
Plant species composition & 3450.000 & 9778.000 & -7.333 & $\mathbf{0 . 0 0 0}$ \\
Water resources and wetland & 6358.500 & 12686.500 & -1.444 & 0.149 \\
Forest distribution and regeneration & 3275.000 & 9603.000 & -7.156 & $\mathbf{0 . 0 0 0}$ \\
\hline
\end{tabular}


Turkish and Swedish experts found "sensitive and rare ecosystems" and "ecosystem structure" indicators equally important. The "plant species composition" indicator was found less important by the Swedish experts (Fig. 3).

\section{Opinions of experts for biodiversity indicators related to conservation status and external factors}

There were no statistically significant differences between the opinions of the Turkish and Swedish experts regarding the importance of forest biodiversity indicators regarding conservation status and external factors (Table 6), and most of the experts deemed these indicators as "important" or "very important" (Fig. 4).

Table 6. Mann-Whitney $U$ test results for the importance of conservation status and external factors indicators

\begin{tabular}{c|c|c|c|c}
\hline Indicators & M-Whitney U & Wilcoxon W & $\mathbf{Z}$ & $\mathbf{p}$ \\
\hline Existence of contaminants around protected areas & 6467.500 & 12795.500 & -1.057 & 0.290 \\
Differentiated conservation status within protected areas & 6226.500 & 12554.500 & -1.341 & 0.180 \\
Effects of other sectors & 6788.500 & 14291.500 & -0.110 & 0.913 \\
Human use of protected areas & 6392.500 & 12720.500 & -1.009 & 0.313 \\
Damaged areas & 6650.000 & 14153.000 & -0.450 & 0.653 \\
Other issues important for sustainable management & 6794.500 & 14297.500 & -0.107 & 0.915 \\
\hline
\end{tabular}

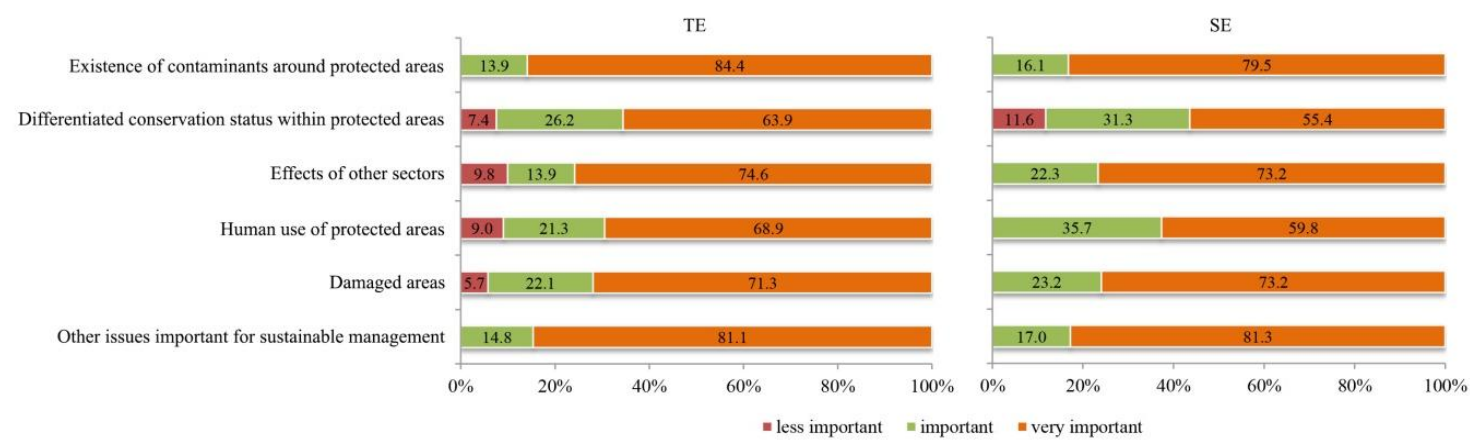

Figure 4. Differences in given level of importance for forest biodiversity indicators related to conservation status and forest structure $\left(n_{T E}=122, n_{S E}=112\right.$, only values $\left.>5 \%\right)$

\section{Ranking for forest biodiversity indicators}

Table 7 presents the ranking of the scores and opinions of the experts for each indicator from the highest score to the lowest according to averages. The averages are calculated from the responses given on a 4-point Likert scale (not important $=1$, less important $=2$, important $=3$ and very important $=4$ ). Accordingly, the top five and last five indicators in the table are indicated with a grey colour. Table 7 shows that only the indicator "forest distribution and regeneration" out of the 23 indicators had an average value of 2.74. The average value of the remaining 22 indicators was above 3 . In general, this indicates that the experts found the indicators appropriate for the study.

The average values of the responses given by the Swedish and Turkish experts regarding the importance level of the indicators reveal that "endemic species" and 
"naturalness" were placed at the top amongst all indicators. This means that experts from both groups found endemic species and naturalness indicators equally important. The indicators for which there were the largest differences in opinion between the Swedish and Turkish experts included "dead wood" and "hollow trees". These indicators were ranked third and fourth, respectively, by Swedish experts, while Turkish experts ranked them fourteenth and eighteenth, respectively. The two indicators where both Turkish and Swedish experts gave the lowest rank and found equally less important were "overused species" and "forest distribution and regeneration". Additionally, "carrying capacity in terms of important species of area" and "the existence of different conservation status of protected areas" were found equally less important (Table 7).

Table 7. Mean scores and rank for the evaluated forest biodiversity indicators

\begin{tabular}{|c|c|c|c|c|c|c|}
\hline \multirow{2}{*}{ Indicators } & \multicolumn{2}{|c|}{$\begin{array}{l}\text { Turkish } \\
\text { experts }\end{array}$} & \multicolumn{2}{|c|}{$\begin{array}{c}\text { Swedish } \\
\text { experts }\end{array}$} & \multicolumn{2}{|c|}{ Total } \\
\hline & Mean & Rank & Mean & Rank & Mean & Rank \\
\hline Endemic species & 3.90 & 1 & 3.88 & 2 & 3.89 & 1 \\
\hline Naturalness & 3.81 & 5 & 3.92 & 1 & 3.86 & 2 \\
\hline Endangered species & 3.89 & 2 & 3.83 & 6 & 3.86 & 3 \\
\hline Genetic resources & 3.80 & 6 & 3.83 & 5 & 3.81 & 4 \\
\hline Water resources and wetland & 3.83 & 3 & 3.76 & 9 & 3.79 & 5 \\
\hline Existence of contaminants around protected areas & 3.83 & 4 & 3.74 & 10 & 3.79 & 6 \\
\hline Sensitive and rare ecosystems & 3.80 & 7 & 3.77 & 8 & 3.78 & 7 \\
\hline Other issues important for the sustainable management & 3.76 & 9 & 3.79 & 7 & 3.78 & 8 \\
\hline Dead wood & 3.64 & 14 & 3.84 & 4 & 3.74 & 9 \\
\hline Hollow trees & 3.57 & 18 & 3.88 & 3 & 3.72 & 10 \\
\hline Species whose lives depend on protected areas & 3.76 & 8 & 3.61 & 15 & 3.69 & 11 \\
\hline Ecosystem structure & 3.66 & 13 & 3.70 & 12 & 3.68 & 12 \\
\hline Species whose distribution area is declining and habitat loss & 3.75 & 11 & 3.60 & 16 & 3.68 & 13 \\
\hline Damaged areas & 3.64 & 15 & 3.70 & 13 & 3.67 & 14 \\
\hline Effects of other sectors & 3.61 & 16 & 3.69 & 14 & 3.65 & 15 \\
\hline Major distribution areas and population status of the species & 3.68 & 12 & 3.57 & 17 & 3.63 & 16 \\
\hline Litter layer & 3.51 & 21 & 3.74 & 11 & 3.62 & 17 \\
\hline Human use of protected areas & 3.58 & 17 & 3.55 & 18 & 3.57 & 18 \\
\hline Differentiated conservation status within protected areas & 3.52 & 20 & 3.40 & 19 & 3.46 & 19 \\
\hline Plant species composition & 3.75 & 10 & 3.08 & 21 & 3.43 & 20 \\
\hline Carrying capacity in terms of important species of area & 3.53 & 19 & 3.27 & 20 & 3.41 & 21 \\
\hline Overused species & 3.48 & 22 & 2.71 & 22 & 3.11 & 22 \\
\hline Forest distribution and regeneration & 3.25 & 23 & 2.18 & 23 & 2.74 & 23 \\
\hline
\end{tabular}

Other indicators with large differences were "plant species composition," as this was ranked tenth by Turkish experts and only twenty-first by Swedish experts. On the contrary, "litter layer" was ranked eleventh by Swedish experts and twenty-first by Turkish experts and was found less important than other indicators. The sometimes-diverging opinions between the groups are interesting, and can be helpful in defining the most important forest 
biodiversity indicators. The dynamic and varying structure of the indicators contribute positively to the identification of the best indicators for a given region.

\section{Discussion}

Dead wood and hollow trees represent structures of great importance for biodiversity and ecosystem health in forests. They provide important habitats for many species. Furthermore, they play a crucial role in increasing the resilience of forests and ensuring the continuity of ecological balance. Dead wood is a critical source for forest biodiversity and is commonly used as an indicator for sustainable forest management (Jonsson et al., 2016). Although the importance of dead wood for biodiversity is commonly known, directed strategies for protection of dead wood in forest ecosystems are implemented only in some of the regions across the world (Seibold et al., 2015). The most important difference among indicators is "dead wood" and "hollow trees" according to the experts in this study. Turkish experts found these indicators less important. One reason for this may be because of the common belief in Turkey that the existence of dead wood and hollow trees results in entomological pest species outbreaks (bark beetles, etc.) and may have implications for protected areas, for example by increasing the risk of forest fires. On the contrary, hollow trees have for a long time been known among Swedish foresters and biologists as very important for cavity nesting birds and many saproxylic invertebrates (Ehnström and Waldén, 1986; Nilsson and Baranowski, 1994; Ranius and Jansson, 2000). For Turkish conditions, similar results have been found in recent studies (Jansson and Coskun, 2008; Sama et al., 2011; Bergner et al., 2016), but this knowledge is still new and not commonly acknowledged in Turkish society.

Swedish experts found the "naturalness" indicator more important. This may be because of the opinion in Sweden that a desirable management regime in many protected forest areas is to make them look as "untouched" as possible (Steinwall, 2015). Turkish experts found the indicators for "plant species composition" and "forest distribution and regeneration" more important. One reason for this may be that the question of whether or not silvicultural treatments should be implemented in the protected areas of Turkey is still controversial. This debate exists because the affected areas are impacted to a certain extent by anthropogenic factors that are sometimes from entomological pest species outbreaks and an increased risk of forest fire (Colak, 2001; Alptekin et al., 2010). In Sweden there are lower risks for wild fires, and in some forest habitats wild fires are seen as positive and a part of the natural disturbance regime in the northern taiga forest ecosystem (Drobyshev et al., 2012).

The indicators for "sensitive and rare ecosystems" and "ecosystem structure" are used for monitoring, particularly in protected areas (Akyol and Tolunay, 2014). These ecosystems are jeopardized by the global climate change (Williams et al., 2015). Climate change may have multiple effects such as those related to the dynamics of species within ecosystems and abiotic factors that may have implications for ecosystems, such as forest fire dynamics (Costanza et al., 2016). Turkish and Swedish experts found these indicators equally important. It is also important to monitor "plant species composition" and put this in relation to these effects (Seidl et al., 2014; Pommerening et al., 2016), but in this study the Swedish experts found this less important than Turkish experts. 
Regarding biodiversity indicators related to conservation status and external factor, there were same opinions between the two expert groups and these indicators were found important or very important. Similar to most developing countries, a rigid and conservative approach is dominant in Turkey. This is the reason why local people are usually excluded from the planning and management of protected areas in Turkey. This approach is based on the assumption that a natural resource can be protected by prohibiting or restricting its exploitation as a natural resource by law (Rutagarama and Martin, 2006). This approach leads to a conflict between managers and users from the perspective of objectives set for the protected areas, since the aims of the resource managers are to minimize or prevent the utilization of these resources while users try to increase their utilization of the resources or at least maintain the same level of exploitation (Alkan, 2009; Alicia et al., 2018). Ultimately, rigid and passive protection approaches fail because there is dependence by local people on the natural resources in or around protected areas. This is especially the case in developing countries, where use could not be eliminated and alternative sources of income could not be provided to locals who are already in difficult socioeconomic situations. As such, protection often times exists only on paper (Akyol et al., 2017; Alkan et al., 2009; Alkan and Korkmaz, 2009; Thomas and Middleton, 2003; WWF, 2003; Arias et al., 2000).

\section{Conclusions}

It is important to monitor and assess biodiversity and sustainability in protected areas. Suitable indicators for protected areas have not been developed from the perspective of biodiversity and sustainable forest management. This study analysed a set of forest biodiversity indicators developed in international processes and solicited opinions from Turkish and Swedish forest experts to compare and analyse the indicators.

Although the overall ranking order differed, the first nine indicators were ranked the same by both expert groups and the top four indicators in total when adding the two groups together were among top six for both groups. These indicators were: "endemic species", "naturalness" "endangered species" and "genetic resources". The indicators with the lowest rankings in total and for both expert groups were "overused species" and "forest distribution and regeneration".

Indicators with significant importance ranking differences were "dead wood" and "hollow trees". This has important implications. Recent studies have shown very high biodiversity in old hollow oaks in Turkey, and thus these studies should be expanded to also cover other tree species and dead wood in general in Turkish forests. Naturally it takes time before results from scientific studies gains acceptance in society, and as such differences may be in part due to such a time lag in distributing knowledge.

The results also reveal different perceptions on the importance of such structures amongst people from different biogeographical regions, and hence environmental conditions may result in different perspectives on nature management. The differences should be considered an advantage in the process of developing improved biodiversity indicators as both groups could benefit from each other's experiences in these matters.

There is a need for further studies to evaluate the measurability of these indicators and to identify indicators that are the most cost-effective and reliable for measurement and quantification. It is also preferable if these indicators can be monitored in a standardized manner to ensure non-biased long-term data regarding indicator dynamics 
and how they relate to external factors, such as climate change. The set of indicators assessed in this study are a first step in the process of developing appropriate indicators for biodiversity in protected areas. This research provides a solid base and a guideline for the next step in the process.

\section{REFERENCES}

[1] Akyol, A., Tolunay, A. (2014): Modelling of sustainable forest management criteria and indicators for Turkey. - SDU Faculty of Forestry Journal 15: 21-32.

[2] Akyol, A., Türkoğlu, T., Bekiroğlu, S., Tolunay, A. (2017): Resident perceptions of livelihood impacts arising from the Kizıldağ National Park, Turkey. - Environ Dev Sustain 2017. DOI: 10.1007/s10668-017-9921-0.

[3] Alicia, P.-L., Francisco, M. O-.P., Ignacio, H.-C., José, L. R.-C, Francisco, A. S.-B. (2018): Analysing social perception as a key factor in the management of protected areas: the case of the Sierra Nevada Protected Area (S Spain). - Journal of Environmental Planning and Management 61(1): 124-142.

[4] Alkan, H. (2009): Negative impacts of rural settlements on natural resources in the protected areas: An example from Kovada Lake National Park. - Journal of Environmental Biology 30(3): 363-372.

[5] Alkan H, Korkmaz, M. (2009): Experienced in the management of protected areas with a focus on socio-economic assessment of the problems. - II. Socio-economic Issues in Forestry Congress, Isparta, Turkey, 19-21 February 2009, pp. 13-22.

[6] Alkan, H., Korkmaz, M., Tolunay, A. (2009): Assessment of primary factors causing positive or negative local perceptions on protected areas. - Journal of Environmental Engineering and Landscape Management 17(1): 20-27.

[7] Alptekin, C., U., Imal, B., Oner, N. (2010): Silvicultural precautions for natural protected areas and national parks in Turkey. - III. National Black Sea Forestry Congress, Artvin, Turkey, 20-22 May 2010, pp. 915-926.

[8] Arias, M. C., Valery, A. I., Faria, H. H. (2000): Measuring Protected Area Management Effectiveness. - Forest Innovations Project, WWF/GTZ/IUCN Technical Series, No: 2, WWF, Turrialba, Costa Rica, pp. 1-105.

[9] Bajracharya, S. B., Furley, P. A., Newton, A. C. (2005): Effectiveness of community involvement in delivering conservation benefits to the Annapurna Conservation Area, Nepal. - Environmental Conservation 32: 239-247.

[10] Bergner, A., Sunnergren, A., Yeşilbudak, B., Erdem, C., Jansson, N. (2016): Attributes of trees used by nesting and foraging woodpeckers (Aves: Picidae) in an area with old pollarded Oaks (Quercus spp.) in the Taurus Mountains, Turkey. - Zoology in the Middle East 62(4): 288-298.

[11] Blicharska, M., Angelstam, P., Antonson, H., Elbakidze, M., Axelsson, R. (2011): Road, forestry and regional planners' work for biodiversity conservation and public participation: A case study in Poland's hotspots regions. - Journal of Environmental Planning and Management 4: 1373-1395.

[12] Brang, P., Courbaund, B., Fisher, A., Kissling-Näf, I., Pettenella, D., Schönenberger, W., Spörk, J., Grimm, V. (2002): Developing indicators for the sustainable management of mountain forests using a modelling approach. - Forest Policy and Economics 4: 113-123.

[13] Castañeda, F. (2000): Criteria and indicators for sustainable forest management: International processes, current status and the way ahead. - Unasylva 51(203): 34-40.

[14] Castañeda, F., Palmberg-Lerche, C., Vuorinen, P. (2001): Criteria and Indicators for Sustainable Forest Management: A Compendium. - Forest Management Working Paper No 5. Forest Resources Development Service, Rome, Italy. 
[15] CCFM (2004): Defining sustainable forest management in Canada criteria and indicators 2003. Canadian Council of Forest Ministers (CCFM). www.ccfm.org/ci/CI2003_tech_sup_1.pdf (accessed on 20 June 2016).

[16] CIFOR (1999): The CIFOR criteria and indicators generic template. - The Criteria \& Indicators Toolbox Series 2, Bogor, Indonesia.

[17] Claridge, M. F., Dawah, H. A., Wilson, M. R. (1997): Species: The Units of Biodiversity. - Chapman \& Hall, London.

[18] Colak, A. H. (2001): Nature Conservation in the Forest (Concepts-Principles-StrategiesPrecautions). - General Directorate of Nature Conservation and National Publication: Ankara, Turkey.

[19] Costanza, J., Beck, S., Pyne, M., Terando, A., Rubino, M., White, R., Collazo, J. (2016): Assessing Climate-Sensitive Ecosystems in the Southeastern United States. - U. S. Geological Survey Open-File Report 2016-1073.

[20] Drobyshev, I., Niklasson, M., Linderholm, H. W. (2012): Forest fire activity in Sweden: Climatic controls and geographical patterns in 20th century. - Agricultural and Forest Meteorology 154-155: 174-186.

[21] Duelli, P., Obrist, M. K. (2003): Biodiversity indicators: The choice of values and measures. - Agriculture, Ecosystems \& Environment 98(1): 87-98.

[22] Ehnström, B., Waldén, H. W. (1986): Faunavård iskogsbruket (The protection and management of endangered and declining invertebrate species in Swedish woodland). Swedish Forest Agency, Jönköping (in Swedish).

[23] FAO (1996): FAO/UNEP Expert Meeting on Criteria and Indicators for Sustainable Forest Management in the Near East, October 15-17, Cairo, Egypt. - FAO, Rome.

[24] FAO (1997): Criteria and Indicators for Sustainable Forest Management in Central America. Expert Meeting, January 20-24, Tegucigalpa, Honduras. - FAO, Rome.

[25] FAO (2003): Practical Guidelines for the Assessment, Monitoring and Reporting on National Level Criteria and Indicators for Sustainable Forest Management in Dry Forests in Asia. Food and Agriculture Organization of the United Nations Regional Office for Asia and the Pacific, Thailand. - FAO, Rome.

[26] FAO (2004): FAO/ITTO Expert Consultation on Criteria and Indicators for Sustainable Forest Management. 2-4 March 2004, Cebu City, Philippines. - FAO, Rome.

[27] FAO (2010): Criteria and Indicators for Sustainable Forest Management: A Compendium. - Food and Agriculture Organization of the United Nations, Forest Management Working Paper FM/5, Rome, Italy.

[28] Gaston, K. J. (1996): What is Biodiversity? - In: Gaston, K. J. (ed.) A Biology of Numbers and Difference. Blackwell Scientific Publications, London.

[29] Grainger, A. (2012): Forest sustainability indicator systems as procedural policy tools in global environmental governance. - Global Environmental Change 22(1): 147-160.

[30] Gülsoy, S., Özkan, K. (2008): Importance of biodiversity from the ecological standpoint and some diversity indexes. - SDU Faculty of Forestry Journal 1: 168-178.

[31] Hagan, J. M., Whitman, A. A. (2006): Biodiversity indicators for sustainable forestry: Simplifying complexity. - Journal of Forestry 104(4): 203-210.

[32] Heink, U., Kowarik, I. (2010): What criteria should be used to select biodiversity indicators? - Biodiversity and Conservation 19: 3769-3797.

[33] ITTO (1992): Criteria for the Measurement of Sustainable Tropical Forest Management. - ITTO Policy Development Series No. 3. Publisher: International Tropical Timber Organization: Yokohama, Japan.

[34] ITTO (2003): ATO/ITTO Principles, Criteria and Indicators for the Sustainable Management of African Natural Tropical Forests. A Collaboration between the African Timber Organization and the International Tropical Timber Organization. - ITTO Policy Development Series No: 14. International Timber Organization, Yokohama, Japan. 
[35] ITTO (2005): Revised ITTO Criteria and Indicators for the Sustainable Management of Tropical Forests Including Reporting Format. - ITTO Policy Development Series No: 15. International Timber Organization, Yokohama, Japan.

[36] Jansson, N., Coskun, M. (2008): How similar is the saproxylic beetle fauna on old oaks (Quercus spp.) in Turkey and Sweden? - Revue d'Ecologie (Terre et Vie) Suppl. 10: 91-99.

[37] Jonsson, B. G., Ekström, M., Esseen, P. A., Grafström, A., Ståhl, G., Westerlund, B. (2016): Dead wood availability in managed Swedish forests-policy outcomes and implications for biodiversity. - Forest Ecology and Management 376: 174-182.

[38] Kotwal, P. C., Omprakash, M. D., Gairola, S., Dugaya, D. (2008): Ecological indicators: Imperative to sustainable forest management. - Ecological Indicators 8(1): 104-107.

[39] Lindermayer, D. B., Margules, C. R., Botkin, D. B. (2000): Indicators of biodiversity for ecologically sustainable forest management. - Conservation Biology 14(4): 941-950.

[40] McDonald, G. T., Lane, M. B. (2004): Converging global indicators for sustainable forest management. - Forest Policy and Economics 6(1): 63-70.

[41] MCPFE (2006): Inter-Criteria and Indicators (C\&I) Process Collaboration Workshop. Ministerial Conference on the Protection of Forest in Europe, Warsaw, Poland.

[42] Mendoza, G.; Prabhu, R. (2000): Development of a methodology for selecting criteria and indicators of sustainable forest management: A case study on participatory assessment. - Environmental Management 26(6): 659-673.

[43] MPCI, 2017. Criteria and Indicators for the Conservation and Sustainable Management of Temperate and Boreal Forests. - www.rinya.maff.go.jp/j/kaigai/pdf/2009p_4.pdf (accessed on 15 January 2018).

[44] Mrozek, T., Balsillie, D., Schleifenbaum, P. (2006): Field testing of a criteria and indicators system for sustainable forest management at the local level. Case study results concerning the sustainability of the private forest Haliburton Forest and Wild Life Reserve in Ontario, Canada. - Forest Policy and Economics 8: 593-609.

[45] Nachar, N. (2008): The Mann -Whitney U: A test for assessing whether two independent samples come from the same distribution. - Tutorials in Quantitative Methods for Psychology 4: 13-20.

[46] Nilsson, S. G., Baranowski, R. (1994): Indicators of mega tree continuity - Swedish distribution of click beetles (Coleoptera, Elateridae) dependent on hollow trees. Entomologisk Tidskrift 115: 81-97.

[47] Nulty, D. D. (2008): The adequacy of response rates to online and paper surveys: What can be done? - Assessment \& Evaluation in Higher Education 33(3): 301-314.

[48] Pommerening, A., Brzeziecki, B., Binkley, D. (2016): Are long-term changes in plant species composition related to asymmetric growth dominance in the pristine Białowieża forest? - Basic and Applied Ecology 17(5): 408-417.

[49] Purnomo, H., Mendoza, G. A., Prabhu, R. (2005): Analysis of local perspectives on sustainability forest management: An Indonesian case study. - Journal of Environmental Management 74: 111-126.

[50] Rametsteiner, E. (2001): SFM Indicators as Tools in Political and Economic Contexts: Actual and Potential Roles. - In: Raison, R. J., Brown, A. G., Flinn, D. W. (eds.) Criteria and Indicators for Sustainable Forest Management. CABI Publishing, New York, USA.

[51] Ranius, T., Jansson, N. (2000): The influence of forest regrowth, original canopy cover and tree size on saproxylic beetles associated with old oaks. - Biological Conservation 95: 85-94.

[52] Rutagarama, E., Martin, A. (2006): Partnerships for protected area conservation in Rwanda. - The Geographical Journal 172(4): 291-305.

[53] Sama, G., Jansson, N., Avci, M., Sarikaya, O., Coskun, M., Kayis, T., Özdikmen, H. (2011): Preliminary report on a survey of the saproxylic beetle fauna living on old hollow oaks (Quercus spp.) and oak wood in Turkey. - Munis Entomology \& Zoology 6(2): 819831. 
[54] Seibold, S., Bassler, C., Brandl, R., Gossner, M. M., Thorn, S., Ulyshen, M. D., Muller, J. (2015): Experimental studies of dead-wood biodiversity-a review identifying global gaps in knowledge. - Biological Conservation 191: 139-149.

[55] Seidl, R., Rammer, W., Spies, T. (2014): Disturbance legacies increase the resilience of forest ecosystem structure, composition, and functioning. - Ecol. Appl. 24: 2063-2077.

[56] Siry, J. P., Cubbage, F. W., Ahmed, M. R. (2005): Sustainable forest management: Global trends and opportunities. - Forest Policy and Economics 7(4): 551-561.

[57] WWF (2003): State of Europe's forest protection: WWF European Forest Programme. 4th Ministerial Conference on the Protection of Forests in Europe, Vienna, Austria.

[58] Steenberg, J. W. N., Duinker, P. N., Van Damme, L., Zielke, K. (2013): Criteria and indicators of sustainable forest management in a changing climate: an evaluation of Canada's national framework. - J. Sustain. Dev. 6: 32-64.

[59] Steinwall, A. (2015): Naturalness or biodiversity: negotiating the dilemma of intervention in Swedish protected area management. - Environmental Values 24: 31-54.

[60] Svancara, L. K., Brannon, R., Scott, J. M., Groves, C. R., Noss, R. F., Pressey, R. L. (2005): Policy-driven versus evidence-based conservation: A review of political targets and biological needs. - BioScience 55(11): 989-995.

[61] Thomas, L., Middleton, J. (2003): Guidelines for management planning of protected areas. - IUCN Gland, Switzerland and Cambridge, UK.

[62] Tolunay, A., Akyol, A. (2015): Identify of appropriate biodiversity indicators for ecologically sustainable forest management at national level. - Sains Malaysiana 44(2): 159-166.

[63] UNDP (2017): Integrated Approach to Management of Forests in Turkey, with Demonstration in High Conservation Value Forests in the Mediterranean Region. http://www.tr.undp.org/content/turkey/en/home/projects/integrated-approach-tomanagement-of-forests-in-turkey--with-dem.html (accessed on 15 March 2017).

[64] Wells, M., McShane, T. O. (2004): Integrating protected area management with local needs and aspirations. - Ambio 33: 513-519.

[65] Williams, R. J., Wahren, C.-H., Stott, K. A. J., Camac, J. S., White, M., Burns, E., Harris, S., Nash, M., Morgan, J. W., Venn, S., Papst, W. A., Hoffmann, A. A. (2015): An International Union for the Conservation of Nature Red List ecosystems risk assessment for alpine snow patch herb fields, South-Eastern Australia. - Austral Ecology 40(4): 433-443.

[66] Wolfslehner, B., Vacik, H., Lexer, M. (2005): Application of the analytic network process in multi-criteria analysis of sustainable forest management. - Forest Ecology and Management 207: 157-170. 